\title{
The Evolution of Education
}

\section{The American College and the Culture of Aspiration, 1915-1940}

By DAVID O. LEVINE. "In a narrative that is intelligently presented, well organized, and swarming with information on a subject that deserves the attention given to it, the author skillfully describes how conservatives mouthed the platitudes of a liberal, democratic ethos of opportunity-the American Dream-and then acted effectively to delimit and structure the consequences." - Burton J. Bledstein, History of Education Quarterly.

Is higher education a right or a privilege? Who should go to college, and what should they study there? These questions were hotly debated between the world wars, when an unprecedented boom in college enrollments forced Americans to weigh their belief in the importance of educational opportunity and their desire to preserve the existing social structure. Levine offers the first in-depth history of higher education during this era. $\$ 9.95$ paper

\section{Available again... \\ Women at Cornell The Myth of Equal Education}

By CHARLOTTE WILLIAMS CONABLE. A pioneer in coeducation, Cornell University was the first major institution in the East to admit women and initially offered similar opportunities for men and women. Policies soon changed, however, as a resultof economic and social pressures, and women were confined to a minority of the student body. Conable documents how this development led to a pattern of limited opportunity for women. She takes note of gains for women since the 1960 s and defines the further changes that must take place if women and men are to be offered a truly equal higher education. $\$ 8.95$ paper

\section{Cornell University Press 124 Roberts Place Ithaca, NY 14850}




\section{SIR}

ROBERT

FALCONER

A BIOGRAPHY

James G. Greenlee
Biblical scholar, social critic, and internationalist, Robert Alexander

Falconer was also the foremost Canadian university leader of his generation, serving as president of the University of Toronto from 1907 to 1932 . James Greenlee's biography chronicles his development as an academic leader and a public man.

\section{UNIVERSITY ()F TOR() NTO PRFSS}

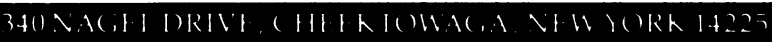

\section{The Making of an American High School}

The Credentials Market and the Central High School of Philadelphia, 1838-1939

David F. Labarec

An analytical study of the origins and development of Central High School, the first high school in Philadelphia and a model for secondary schools elsewhere. Using Central as a case study, David F. Labarec argues that the American public high school is a product of a continuing struggle between democratic political ideals and capitalist elitism and that this struggle helps explain both the twists and turns of its historical development and its current image as an institution in crisis. $\$ 30.00$

\section{Early Schooling}

\section{The National Debate}

edited by Sharon L. Kagan and Edward F. Zigler

In this "important and useful" book (Bernard Spodek), well-know'n scholars and practitioners such as Albert Shanker, David Elkind, David P. Weikart, and Ser'mour

Sarason present a varicty of view's about carly' schooling. $\quad \$ 24.00$

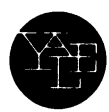

Yale University Press

1)ept. 712, 92A Yale Station, New Haven, CT O6\$20 


\begin{tabular}{|c|c|}
\hline $\begin{array}{l}\text { The current controversy over the } \\
\text { teaching of values and the role of reli- } \\
\text { gion in our public schools is an impor- } \\
\text { tant and much discussed topic. Stock- } \\
\text { Morton's work represents not only a } \\
\text { valuable historical investigation, but a } \\
\text { useful resource for the review and } \\
\text { consideration of our present-day di- } \\
\text { lemma. France is the only country that } \\
\text { has attempted to teach an official secu- } \\
\text { lar morality and Stock-Morton's is the } \\
\text { first study to describe and trace the } \\
\text { development of that effort. } \\
\text { The history of morale laique is sig- } \\
\text { nificant at a time when our own coun- } \\
\text { try is rife with controversy over the } \\
\text { role of religion and teaching of values } \\
\text { in the schools. Stock-Morton's } \\
\text { thoughtful study is an important con- } \\
\text { tribution to the literature for those } \\
\text { concerned with these significant } \\
\text { issues. }\end{array}$ & $\begin{array}{c}\text { SCHOOLING IN } \\
\text { WESTERN EUROPE } \\
\text { A Social History } \\
\text { Mary Jo Maynes } \\
\text { copies at \$18.95 pb. } \\
\text { * }\end{array}$ \\
\hline
\end{tabular}




\section{The Social History of American Education}

\section{Edited by \\ B. Edward McClellan and William J. Reese}

For over twenty-five years, the History of Education Quarterly has served as the meeting ground for a generation of the leading experts in educational and social history. For the convenience of scholars and students alike, Edward McClellan and William Reese bring together the major ideas of its most prominent contributors. Bridging the span of American educational history from the colonial era to the present, these essays offer extensive coverage of such topics as women's education, the education of minority groups, and the social dimensions of educational reform.

Contributors: David F. Allmendinger, Jr., James D. Anderson, Jurgen Herbst, N. Ray Hiner, Michael B. Katz, Marvin Lazerson, Katherine McDaniel Moore, Michael R. Olneck, David N. Plank, Paul E. Peterson, Mary Aicken Rothschild, John L. Rury, Guadalupe San Miguel, Jr., Anne Firor Scott, Ronald Story, Marcia G. Synnott, Jon Teaford, Selwyn Troen, and David B. Tyack.

"These essays represent some of the best and most significant contributions to the reconceptualized field of history of education that have been published in recent years." - Jennings L. Wagoner, past president of the History of Education Society and co-editor of The Changing Politics of Education. \$34.95; paper, \$11.95.

All royalties on these books are paid to the History of Education Quarterly.

Order from your local bookstore, or from UNIVERSITY OF ILLINOIS PRESS c/o CUP Services - P. O. Box 6525 - Ithaca, NY 14851

Order toll free 800/666-2211 


\section{History \\ of Education \\ Quarterly}

The History of Education Quarterly publishes:

- Articles

- Documents

- Debates on important issues in the history of education

- Retrospectives

- Book reviews

- Film reviews

- Book notes

Topics span the history of education, both formal and nonformal, including the history of childhood, youth, and the family. These subjects are not limited to any time period and are universal in scope. The Quarterly is published in cooperation with the School of Education, Indiana University, with additional support from Indiana University-Northwest.

The History of Education Society

Individual subscription to the Quarterly includes membership in the History of Education Society. The Society is an international organization that seeks to encourage research in the history of education, to improve the teaching of the history of education, to promote the preservation of source materials in history of education, and to interest the educational profession and the general public in the value of the historical perspective in the making of educational policy.

Subscription rates (per calendar year only):

$\begin{array}{lll} & \text { US } & \text { Non-US } \\ \text { Individual (Non-Student) } & \$ 25 & \$ 27 \\ \text { Student } & \$ 15 & \$ 17 \\ \text { Institutions } & \$ 47 & \$ 50\end{array}$

Please address all subscription orders to:

HISTORY OF EDUCATION QUARTERLY

School of Education

Indiana University

Bloomington, IN 47405

Payment must be made in US dollars only 
